\title{
KEPUTUSAN INVESTASI INVESTOR INDIVIDU BERDASARKAN KOMPETENSI, OVERCONFIDENCE, DAN PENDIDIKAN.
}

\author{
Hendang Tanusdjaja \\ Dept. Akuntansi, FE. Universitas Tarumanagara, Jakarta \\ hendangt@gmail.com
}

\begin{abstract}
ABSTRAK
Konsep behavioral finance menyimpulkan bahwa keputusan investasi yang dilakukan oleh investor lebih mempertimbangkan aspek-aspek non-ekonomi terutama aspek psikologis yang dapat mempegaruhi perilaku investor. Studi ini bertujuan mencari bukti pengaruh kompetensi,overconfidence investor bersama dengan variabel kontrol faktor demografi (jenis kelamin, usia, pendidikan, dan pendapatan)terhadap keputusan investasi investor individu. Data dikumpulkan melalui kuesioner dikirimkan kepada 150 responden investor individu di Jakarta dan kembali serta dapat diolah 78 kuesioner. Data dianalisis dengan menggunakan analisis path dan regresi berganda guna menguji hipotesis. Hasil studi menunjukkan kompetensi dan overconfidence signifikan positif mempengaruhi keputusan investasi. Sementara pendidikan investor individu merupakan faktor yang paling mempengaruhi keputusan investor individu.investor yang pendidikannya tinggi memiliki pengetahuan yang lebih banyak mengenai pergerakan saham dan lebih berani dalam mengambil resiko sehingga pengambilan keputusannya dalam berinvestasi lebih besar dibandingkan dengan investor yang pendidikannya lebih rendah
\end{abstract}

Kata kunci : kompetensi, financial literacy, overconfidence, pendidikan, keputusan investasi

\section{PENDAHULUAN}

Perkembangan pasar modal di Indonesia cukup pesat didorong regulasi di bidang keuangan dan perbankan. Pada Desember 2014 investor di pasar modal mencapai 466.250 investor terjadi peningkatan sebesar 14\% dibandingkan tahun 2013 yang mencapai 408.045 investor (idx.co.id:2015). Bursa Efek Indonesia (BEI) selaku pengelola penjualan efek di Indonesia terus melakukan upaya-upaya untuk meningkatkan investasi masyarakat di pasar modal.

Keputusan untuk memilih menempatkan dana pada saham melibatkan faktor-faktor kognitive maupun emosi manusia selaku investor. Secara rasional investor akan memilih saham-saham yang menguntungkan dengan mempertimbangkan tingkat return dan risiko dari saham tersebut. Tetapi faktor emosi menjadikan investor cenderung tidak rasional dalam memilih saham yang tidak menguntungkan, karena kesalahan menganalisis dan menterjemahkan informasi terhadap harga saham yang tidak tepat.

Kebanyakan investor berinvestasi dengan mempertimbangkan faktor informasi akuntansitanpa mempertimbangkan faktor-faktor yang lain.Faktor psikologi ikut menentukan keputusan investasi. Bahkan, berbagai pihakberpendapat faktor psikologi investor ini mempunyai peran yang paling besar dalam berinvestasi. Rasional terikat (bounded rationality) dalam berinvestasi. Investor selalu melakukan hal tidak rasional, misalnya Manajer investasi menawarkan investasi dengan tingkat pengembalian $12 \%$ per tahun dan investasi yang sama ditawarkanpihak lain dengan tingkat pengembalian $11 \%$ per tahun. Keputusan investor memilih investasi yang ditawarkan pihak lain tersebut. Padahal tingkat pengembaliannya dibawah penawaran manager investasi.Investor menjual secepatnya saham yang dimiliki bila kelihatan sudah untung dan menahan saham sangat lama ketika harga saham turun (Shefrin, 1985). Kasus ini memperlihatkan investor tidak mau mengalami kerugian atas investasi yang dimilikinya. Saham yang harganya turun tidak dijual sampai harga saham tersebut naik kembali yaitu sampai mendapatkan sedikit keuntungan baru dijualnya. Padahal, literatur investasi menjelaskan bahwa saham merupakan investasi untuk jangka panjang. Bahkan sudah ada penelitian yang menyimpulkan bahwa memegang saham dalam jangka panjang sama hasilnya dengan melakukan perdagangan saham itu pada periode yang sama dengan menahan saham itu dalam jangka panjang.

Faktor psikologi mempengaruhi seseorang dalam berinvestasi dan hasil yang akan dicapai. Analisis berinvestasi menggunakan ilmu psikologi dan ilmu keuangan dikenal sebagai tingkah laku atau perilaku keuangan (Behaviour Finance). Shefrin (2000) mendefinisikan behaviour finance adalah studi yang mempelajari bagaimana fenomena psikologi mempengaruhi tingkah laku keuangannya.

Konsep behavioral finance menyimpulkan bahwa keputusan investasi yang dilakukan oleh investor lebih mempertimbangkan aspek-aspek non-ekonomi terutama aspek psikologis yang dapat mempegaruhi perilaku 
investor. Investor dalam kenyataannya seringkali melakukan tindakan berdasarkan judgment dan bertentangan dengan teori yang selama ini dikemukakan dalam pasar modal tentang asumsi rasionalitas. Pasar mungkin memberikan reaksi cepat terhadap informasi (seperti yang disyaratkan dalam Efficient Market Hypothesis), namun pengaruh reaksi tersebut justru lebih banyak dipengaruhi oleh unsur subyektifitas, emosi, dan berbagai faktor psikologis lainnya.

Beberapa hasil penelitian mengungkapkan bahwa investor memiliki kecenderungan secara psikologis merespon harga saham ataupun melakukan investasi di pasar modal. Kenyataannya investor tidak selalu bersikap rasional dalam mengambil keputusan investasi. Keputusan investor cenderung dipengaruhi oleh sifat psikologis yang ada dalam dirinya dan salah satu gejala psikologis yang sering menjangkiti para investor di pasar modal adalah ketakutan akan penyesalan (fear of regret) yang menyebabkan mereka raguragu dan bertindak tidak rasional(Suryawijaya, 2003). Hal inilah yang kemudian banyak dipertimbangkan oleh investor dan semakin membawanya menyimpang dari prinsip rasionalitas.

Nagy dan Obenberger (1994) mengklasifikasikan beberapa faktor lain selain Accounting Information dan Self Image/Firm-Image Coincidence yang juga mempengaruhi seorang investor dalam melakukan investasi, yaitu faktor Neutral Information, Classic, Social Relevance Advocate Recommendation, dan Personal Financial Needs. Nagy dan Obenberger (1994)menyimpulkan investor sekarang berbeda, tidak lagi hanya melihat faktor-faktor biasa saja namun juga memperhitungkan faktor-faktor lain sebelum melakukan investasi, dan faktor yang paling diperhitungkan oleh investor pada penelitian Nagy dan Obenberger adalah estimasi keuntungan perusahaan di masa datang yang merupakan variabel economic untuk memaksimalkan kekayaan.

Selain faktor-faktor tersebut, tingkat kompetensi investor juga dapat mempengaruhi investor dalam melakukan perdagangan saham yang diukur melalui tingkat frekuensi transaksi saham oleh investor (Chandra, 2009).Kompetensi investor individu pada perilaku perdagangan investor di pasar saham mempengaruhi perilaku trading.Investor yang merasa lebih kompeten lebih sering melakukan trading.

Kompetensi investor di pasar saham mencerminkan adanya financial literacy yang merujuk pada pemahaman investor mengenai bagaimana pasar keuangan bekerja. Status pendidikan seorang investor secara garis besar dapat menunjukkan seberapa besar financial literacy yang dimiliki oleh investortersebut. Investor dengan latar belakang pendidikan yang lebih tinggi mempunyai kompetensi yang lebih tinggi, dan mereka cenderung untuk mengambil keputusan lebih sering mengenai kegiatan perdagangan di pasar saham. Temuan ini sejalan dengan pemikiran bahwa investor yang berkualitas tinggi akan merasa lebih kompeten di pasar modal dan cenderung untuk bertransaksi lebih banyak dibandingkan dengan investor dengan latar belakang pendidikan yang kurang baik.

Selain kompetensi investor, faktor percaya diri (overconfidence) juga berperan dalam perilaku perdagangan investor.Penelitianempiris menemukan bahwa tingkattrading activity dari seorang investor dipengaruhi oleh tingkat overconfidence dari investor tersebut, semakin investor memiliki overconfidence, semakin sering dia melakukan trading (perdagangan)(Odean, 1999; Barber and Odean, 2001; Statman et.al, 2003; Glaser and Weber (2003) ).

Seorang investor yang overconfidence akan memiliki keyakinan dalam mengambil keputusan dan lebih berani dalam mengambil risiko saat melakukan transaksi saham karena menurut dirinya memiliki kemampuan dan keahlian yang lebih daripada orang lain.

Faktor lain yang dapat mempengaruhi keputusan investasi investor yaitubehavioral motivation yang dapat dilihat dari variabel demografi, seperti jeniskelamin, usia dan pendidikan (Christanti dan Mahastanti, 2011). Usia, jenis kelamin, pendapatan dan pendidikanmempengaruhi pilihan investor untuk keuntungan, dividen dan semua laba yangdiinginkan(Lawellen, Lease dan Schlarbaum, 1977). Selain itu pilihan investasiseseorang lebih berdasar pada gaya hidup dan karakteristik demografinya(Warren et al., 1990)..

Barberand Odean (2001) memberikan bukti empiris bahwa pria lebih beranimenanggung risiko dalam melakukan investasi dibanding wanita. Hal inidisebabkan faktor psikologis pria lebih percaya diri dibanding wanita.Tingkat pendidikan juga mempengaruhi keputusan investasinya, dengan tingkatpendidikan yang sudah tergolong tinggi tidak membuat investor percaya diriuntuk menentukan faktor-faktor mana yang lebih penting. Investor lulusan S1masih mempertimbangkan semua faktor yang berhubungan dengan kegiataninvestasinya (Christanti dan Mahastanti, 2011). 
Faktor demografi juga dapat mempengaruhi investor untuk melakukan pengambilan keputusan ketika berinvestasi(Lutfi, 2010). Karakteristik demografi investor memiliki hubungan yang positif dengan perilaku investor dan jenis investasi yang dipilih.Karakteristik investor dapat mempengaruhi persepsi kompetensi seorang investorGraham et.al (2005). Perbedaan karakteristik demografis investor menyebabkan investor merasa lebih kompeten dalam memahami informasi keuangan dan peluang yang ada disana. Hasil penelitiannya menemukan bahwa investor laki-laki, investor dengan pendapatan yang tinggi, dan memiliki pendidikan yang tinggi lebih memiliki keyakinan bahwa mereka merupakan investor yang kompeten. Kompetensi investor merupakan seberapa besar investor mengetahui dan memahami mengenai produkproduk investasi, hasil dan risiko serta strategi berinvestasi.

Penelitian mengenai perilaku dalam bidang keuangan belum begitu banyak dilakukan. Hal ini dapat terlihat sangat terbatasnya referensi penelitian perilaku dalam bidang manajemen keuangan dan investasi, terutama di Indonesia. Dengan melihat kondisi ini maka studi perilaku dalam bidang keuangan sangat diperlukan. Pengungkapan perilaku yang berkaitan dengan pengaruh kompetensi dan overconfidence investor terhadap keputusan investasi, bersama dengan variabel kontrol, seperti faktor demografi (jenis kelamin, usia, pendidikan, dan pendapatan) menjadi penting dan urgen dilakukan.

\section{TUJUAN PENELITIAN}

1. Menguji pengaruh kompetensi investor bersama dengan variabel kontrol faktor demografi (jenis kelamin, usia, pendidikan, dan pendapatan)terhadap keputusan investasi,

2. Menguji pengaruh overconfidence investor bersama dengan variabel kontrol faktor demografi (jenis kelamin, usia, pendidikan, dan pendapatan)terhadap keputusan investasi

\section{METODE PENELITIAN}

Populasi penelitian ini adalah semua investor yang tercatat di Bursa Efek Indonesia (BEI) khususnya yang berada di Jakarta.

Sampel dari investor individu yang tercatat di BEI khususnya daerah Jakarta dengan convenience sampling. Data diukur dan dikumpulkan melalui kuesioner dan dari 150 kuesioner, dikembalikan responden dan dapat digunakan sebanyak 78 kuesioner.

Tehnik analisis data dengan menggunakan analisis regresi linear berganda dan analisis path

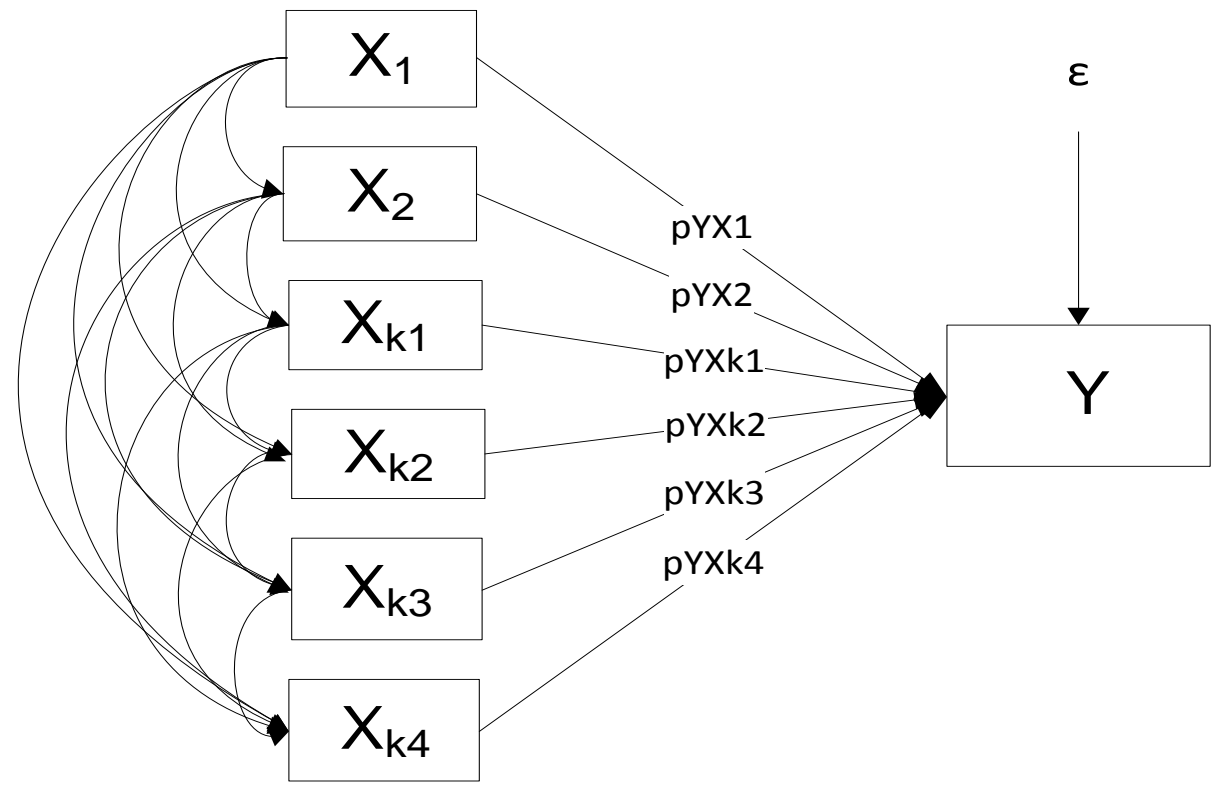

\section{Gambar 1 \\ Model Penelitian}

Adapun persamaan regresi linear berganda dapat dirumuskan sebagai berikut:

$\mathrm{Y}=\beta_{0}+\beta_{1} \mathrm{X}_{1}+\beta_{2} \mathrm{X}_{2}+\beta_{3} \mathrm{X}_{\mathrm{k} 1}+\beta_{4} \mathrm{X}_{\mathrm{k} 2}+\beta_{5} \mathrm{X}_{\mathrm{k} 3}+\beta_{6} \mathrm{X}_{\mathrm{k} 4}+\varepsilon_{0}$ 
Keterangan :

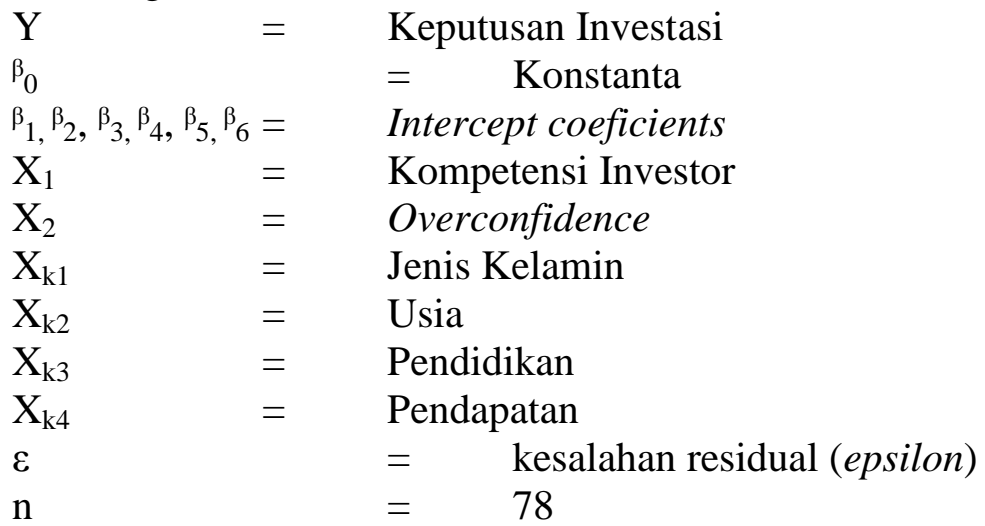

\section{HASIL ANALISIS DATA}

\section{Interpretasi Hasil Penelitian}

Sesuai dengan hasil penelitian yakni: pengaruh kompetensi $\left(\mathrm{X}_{1}\right)$ dan overconfidence $\left(\mathrm{X}_{2}\right)$ terhadap keputusan investasi (Y) dengan adanya variabel kontrol, yaitu faktor demografi (jenis kelamin, usia, pendidikan, dan pendapatan) secara parsial maupun simultan, berikut ini akan dilakukan interpretasi sebagai berikut :

Pengaruh Kompetensi $\left(\mathrm{X}_{1}\right)$ dan Overconfidence $\left(\mathrm{X}_{2}\right)$ Terhadap Keputusan Investasi $(\mathbf{Y})$ dengan Adanya Variabel Kontrol, yaitu Faktor Demografi (Jenis Kelamin, Usia, Pendidikan, dan Pendapatan) Secara Parsial Maupun Simultan

Dalam interpretasi ini, kerangka hubungan kausal empiris antara $X_{1}, X_{2}, X_{k 1}, X_{k 2}, X_{k 3}$, dan $X_{k 4}$ terhadap $Y$ dapat dibuat melalui persamaan regresi linear sebagai berikut:

$\mathrm{Y}=\beta_{0}+\beta_{1} \mathrm{X}_{1}+\beta_{2} \mathrm{X}_{2}+\beta_{3} \mathrm{X}_{\mathrm{k} 1}+\beta_{4} \mathrm{X}_{\mathrm{k} 2}+{ }_{5} \mathrm{X}_{\mathrm{k} 3}+\beta_{6} \mathrm{X}_{\mathrm{k} 4}+\varepsilon_{0}$

Keterangan :

$\begin{array}{lll}\mathrm{Y} & = & \text { Keputusan investasi } \\ \beta_{0} & = & \text { Konstanta } \\ \beta_{1},{ }_{2},{ }_{3}, \beta_{4},{ }_{5},{ }_{6} & = & \text { Intercept coeficients } \\ \mathrm{X}_{1} & = & \text { Kompetensi } \\ \mathrm{X}_{2} & = & \text { Overconfidence } \\ \mathrm{X}_{\mathrm{k} 1} & = & \text { Jenis kelamin } \\ \mathrm{X}_{\mathrm{k} 2} & = & \text { Usia } \\ \mathrm{X}_{\mathrm{k} 3} & = & \text { Pendidikan } \\ \mathrm{X}_{\mathrm{k} 4} & = & \text { Pendapatan } \\ \varepsilon & = & \text { kesalahan residual (epsilon) } \\ \mathrm{n} & = & 78\end{array}$

Tabel 1

Signifikansi dan koefisien

\begin{tabular}{|c|c|c|c|c|c|c|}
\hline & \multirow[b]{2}{*}{ Model } & \multicolumn{2}{|c|}{ Unstandardized Coefficients } & \multirow{2}{*}{$\begin{array}{c}\text { Standardized } \\
\text { Coefficients }\end{array}$} & \multirow[b]{2}{*}{$\mathrm{t}$} & \multirow[b]{2}{*}{ Sig. } \\
\hline & & B & Std. Error & & & \\
\hline \multirow[t]{7}{*}{1} & (Constant) & $-6,337$ & 26,255 & &,- 241 &, 810 \\
\hline & $\mathrm{X} 1$ & ,241 & ,093 &, 265 & 2,610 &, 011 \\
\hline & $\mathrm{X} 2$ &, 534 &, 083 &, 585 & 6,393 &, 000 \\
\hline & $\mathrm{X}_{\mathrm{K} 1}$ &,- 737 & 5,268 &,- 012 &,- 140 & ,889 \\
\hline & $\mathrm{X}_{\mathrm{K} 2}$ & $-1,796$ & 3,373 &,- 048 &,- 532 &, 596 \\
\hline & $\mathrm{X}_{\mathrm{K} 3}$ & 7,053 & 3,422 &, 174 & 2,061 & ,043 \\
\hline & $\mathrm{X}_{\mathrm{K} 4}$ & $-1,335$ & 3,068 &,- 038 &,- 435 &, 665 \\
\hline
\end{tabular}

a. $\quad$ Dependent Variable: $\mathrm{Y}$ (Keputusan Investasi)

Sumber : Hasil Pengolahan Data Penelitian. 
Tabel 2.

ANOVA $^{\mathrm{b}}$

\begin{tabular}{|ll|r|r|r|r|r|}
\hline Model & & Sum of Squares & df & Mean Square & F & Sig. \\
\hline 1 & Regression & 40426,178 & 6 & 6737,696 & 14,230 &, $000^{\mathrm{a}}$ \\
& Residual & 33618,376 & 71 & 473,498 & & \\
& Total & 74044,554 & 77 & & & \\
\hline
\end{tabular}

a. Predictors: (Constant), $\mathrm{X} 1, \mathrm{X} 2, \mathrm{X}_{\mathrm{K} 1}, \mathrm{X}_{\mathrm{K} 2}, \mathrm{X}_{\mathrm{K} 3}, \mathrm{X}_{\mathrm{K} 4}$

b. Dependent Variable: Y (Keputusan Investasi)

Tabel 3

Koefisien Determinasi $\left(\mathbf{R}^{2}\right)$ Kompetensi dan Overconfidence terhadapKeputusan Investasi Model Summary

\begin{tabular}{|l|r|r|r|r|}
\hline Model & $\mathrm{R}$ & \multicolumn{1}{|c|}{ R Square } & Adjusted R Square & $\begin{array}{c}\text { Std. Error of the } \\
\text { Estimate }\end{array}$ \\
\hline 1 &, $739^{\mathrm{a}}$ &, 546 &, 508 & 21,76001 \\
\hline
\end{tabular}

a. Predictors: (Constant), $\mathrm{X} 1, \mathrm{X} 2, \mathrm{X}_{\mathrm{K} 1}, \mathrm{X}_{\mathrm{K} 2}, \mathrm{X}_{\mathrm{K} 3}, \mathrm{X}_{\mathrm{K} 4}$

Sumber : Hasil Pengolahan Data Penelitian.

Correlations

\begin{tabular}{|c|c|c|c|c|c|c|c|c|}
\hline & & $\mathrm{X}_{\mathrm{K} 1}$ & $\mathrm{X}_{\mathrm{K} 2}$ & $\mathrm{X}_{\mathrm{K} 3}$ & $\mathrm{X}_{\mathrm{K} 4}$ & $\mathrm{X} 1$ & $\mathrm{X} 2$ & $\mathrm{Y}$ \\
\hline \multirow{3}{*}{$\mathrm{X}_{\mathrm{K} 1}$} & $\begin{array}{l}\text { Pearson } \\
\text { Correlation }\end{array}$ & 1 & ,006 &,$- 305^{* *}$ &,- 044 &,- 015 & ,098 &,- 010 \\
\hline & Sig. (2-tailed) & &, 956 & ,007 & ,705 & ,896 & ,392 & ,931 \\
\hline & $\mathrm{N}$ & 78 & 78 & 78 & 78 & 78 & 78 & 78 \\
\hline \multirow{3}{*}{$\mathrm{X}_{\mathrm{K} 2}$} & $\begin{array}{l}\text { Pearson } \\
\text { Correlation }\end{array}$ & ,006 & 1 &,- 031 &, 147 &, $450^{* *}$ & ,067 & ,099 \\
\hline & Sig. (2-tailed) & ,956 & &, 788 & ,199 &, 000 & ,560 & ,387 \\
\hline & $\mathrm{N}$ & 78 & 78 & 78 & 78 & 78 & 78 & 78 \\
\hline \multirow{3}{*}{$\mathrm{X}_{\mathrm{K} 3}$} & $\begin{array}{l}\text { Pearson } \\
\text { Correlation }\end{array}$ &,$- 305^{* *}$ &,- 031 & 1 & ,052 &, 041 & ,028 & ,204 \\
\hline & Sig. (2-tailed) & ,007 &, 788 & & ,651 &, 725 & ,808 &, 073 \\
\hline & $\mathrm{N}$ & 78 & 78 & 78 & 78 & 78 & 78 & 78 \\
\hline \multirow{3}{*}{$\mathrm{X}_{\mathrm{K} 4}$} & $\begin{array}{l}\text { Pearson } \\
\text { Correlation }\end{array}$ &,- 044 & , 147 & ,052 & 1 &, $357^{* *}$ &, $326^{* *}$ &, $250^{*}$ \\
\hline & Sig. (2-tailed) & ,705 & ,199 & ,651 & & ,001 & ,004 & ,027 \\
\hline & $\mathrm{N}$ & 78 & 78 & 78 & 78 & 78 & 78 & 78 \\
\hline \multirow{3}{*}{ X1 } & $\begin{array}{l}\text { Pearson } \\
\text { Correlation }\end{array}$ &,- 015 &, $450^{* * *}$ & ,041 &, $357^{* *}$ & 1 &, $409^{* *}$ &, $477^{\text {** }}$ \\
\hline & Sig. (2-tailed) & ,896 &, 000 &, 725 & ,001 & & , 000 & , 000 \\
\hline & $\mathrm{N}$ & 78 & 78 & 78 & 78 & 78 & 78 & 78 \\
\hline \multirow{3}{*}{ X2 } & $\begin{array}{l}\text { Pearson } \\
\text { Correlation }\end{array}$ & ,098 & ,067 & ,028 &, $326^{* *}$ &, $409^{* *}$ & 1 &, $681^{\text {*** }}$ \\
\hline & \begin{tabular}{|l} 
Sig. (2-tailed) \\
\end{tabular} & ,392 &, 560 & ,808 & ,004 & ,000 & &, 000 \\
\hline & $\mathrm{N}$ & 78 & 78 & 78 & 78 & 78 & 78 & 78 \\
\hline \multirow{3}{*}{$\mathrm{Y}$} & $\begin{array}{l}\text { Pearson } \\
\text { Correlation }\end{array}$ &,- 010 & ,099 & 204 & ,250* &, $477^{* * *}$ &, $681^{* *}$ & 1 \\
\hline & Sig. (2-tailed) & ,931 & ,387 & ,073 & ,027 & ,000 & ,000 & \\
\hline & $\mathrm{N}$ & 78 & 78 & 78 & 78 & 78 & 78 & 78 \\
\hline
\end{tabular}

**. Correlation is significant at the 0.01 level (2-tailed).

*. Correlation is significant at the 0.05 level (2-tailed). 


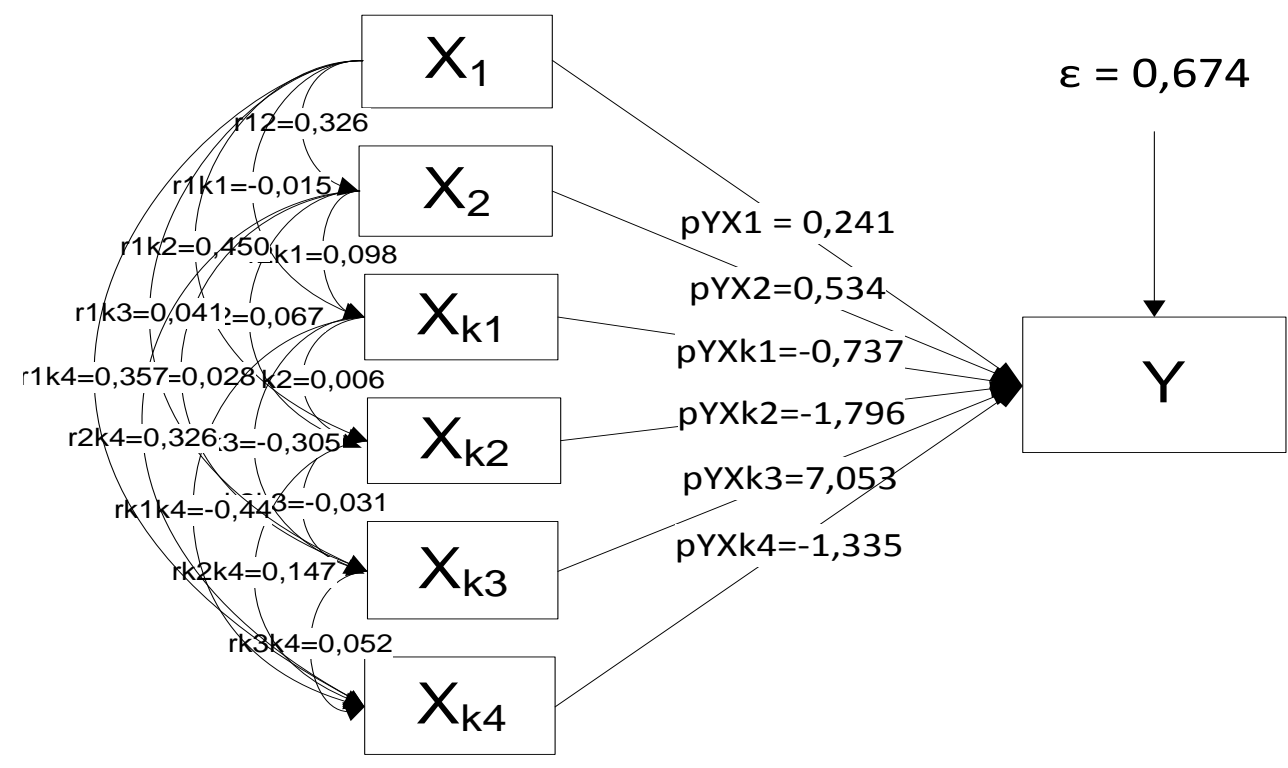

Gambar 2

Path Analysis Hasil Penelitian

Hasil dari pengujian analisis dengan regresi linear berganda seperti pada Gambar 4.5 dapat dibuat menjadi model persamaan regresi dan dijelaskan sebagai berikut :

$\mathrm{Y}=\beta_{0}+\beta_{1} \mathrm{X}_{1}+\beta_{2} \mathrm{X}_{2}+\beta_{3} \mathrm{X}_{\mathrm{k} 1}+\beta_{4} \mathrm{X}_{\mathrm{k} 2}+{ }_{5} \mathrm{X}_{\mathrm{k} 3}+\beta_{6} \mathrm{X}_{\mathrm{k} 4}+\varepsilon_{0}$

$\mathrm{Y}=-6,337+0,241 \mathrm{X}_{1}+0,534 \mathrm{X}_{2}-0,737 \mathrm{X}_{\mathrm{k} 1}-1,796 \mathrm{X}_{\mathrm{k} 2}+7,053 \mathrm{X}_{\mathrm{k} 3}-1,335 \mathrm{X}_{\mathrm{k} 4}+\varepsilon_{0}$

Parsial $=\quad(0,477) \quad(0,681) \quad(-0,010) \quad(0,099)$

$(0,204) \quad(0,250)$

Sig $\mathrm{t}=(0,810)(0,011)^{*}(0,000)^{*}(0,0889) \quad(0,596)$

$(0,043) *(0,665)$

Sig F $=\mathbf{0 , 0 0 0}$

Keterangan :

* $\quad=\quad$ Signifikan

$\mathrm{Y} \quad$ Keputusan Investasi

$\beta_{0} \quad=$ Konstanta

${ }_{1}{ }_{1}{ }_{2},{ }_{3},{ }_{4},{ }^{\beta}{ }_{5},{ }_{6}{ }_{6}=\quad$ Intercept coeficients

$\mathrm{X}_{1} \quad=\quad$ Kompetensi

$\mathrm{X}_{2} \quad=\quad$ Overconfidence

$\mathrm{X}_{\mathrm{k} 1} \quad=\quad$ Jenis Kelamin

$\mathrm{X}_{\mathrm{k} 2} \quad=\quad$ Usia

$\mathrm{X}_{\mathrm{k} 3} \quad=\quad$ Pendidikan

$\mathrm{X}_{\mathrm{k} 4} \quad=\quad$ Pendapatan

$\varepsilon \quad=\quad$ kesalahan residual (epsilon)

$\mathrm{n} \quad=78$

Dari persamaan regresi di atas didapatkan hasil konstanta sebesar -6,337 menyatakan bahwa jika variabel independen, yaitu kompetensi dan overconfidence dianggap konstan, begitu pula dengan variabel kontrol (jenis kelamin, pendidikan, usia, dan pendapatan) maka keputusan investasi seorang investor dinilai buruk. Pernyataan tersebut dapat digambarkan melalui persamaan berikut :

$\mathrm{Y}=-6,337+0,241(5)+0,534(5)-0,737(1)-1,796(1)+7,053(1)-1,335(1)+0,674$

$\mathrm{Y} \quad=1,397$

Angka 1,397 dari variabel keputusan investasi tersebut memiliki arti : 1) dana yang digunakan untuk berinvestasi sebesar Rp1.985.000,-, 2) pengalaman berinvestasi di pasar modal baru 5 bulan, 3) frekuensi 
transaksi saham 4 bulan sekali, dan 4) respon pada saat mengalami kerugian sangat kurang responsif. Oleh karena itu, dapat saya simpulkan bahwa tanpa adanya faktor-faktor yang mempengaruhi keputusan investasi seorang investor sangatlah rendah atau buruk.

Dari persamaan regresi di atas menunjukkan bahwa variabel bebas, yaitu kompetensi investor dan overconfidence memiliki koefisien yang positif terhadap keputusan investasi, selain itu pada variabel kontrol, yaitu pendidikan juga memiliki koefisien yang positif terhadap keputusan investasi. Hal ini memiliki arti jika salah satu variabel tersebut semakin tinggi atau mengalami peningkatan maka keputusan investasi pun akan mengalami peningkatan atau keputusan investasi semakin besar.

Pada saat seorang investor menaikkan kompetensinya dari tidak pernah mengikuti Ujian Standar Profesi Pasar Modal, tidak memiliki sertifikat sama sekali, tidak memiliki pengetahuan dasar mengenai investasi, dan tidak mengetahui metode apapun dalam menganalisis pergerakan saham menjadi pernah mengikuti Ujian Standar Profesi Pasar Modal, memiliki sertifikat, memiliki pengetahuan dasar mengenai investasi, dan mengetahui metode dalam menganalisis pergerakan saham maka keputusan investasi investor tersebut akan mengalami peningkatan. Penjelasan tersebut dapat digambarkan melalui persamaan berikut :

$\mathrm{Y}=-6,337+0,241(10)+0,534(5)-0,737(1)-1,796(1)+7,053(1)-1,335(1)+0,674$

$\mathrm{Y}=2,602$

Angka 2,602 dari variabel keputusan investasi tersebut memiliki arti : 1) dana yang digunakan untuk berinvestasi sebesar Rp6.020.000,-, 2) pengalaman berinvestasi di pasar modal sudah 6 tahun, 3) frekuensi transaksi saham 4 bulan sekali, dan 4) respon pada saat mengalami kerugian cukup responsif. Oleh karena itu, dapat saya simpulkan bahwa ketika seorang menaikkan kompetensinya maka keputusan investasinya akan mengalami peningkatan juga.

Pada saat seorang investor menaikkan kepercayaan dirinya dari tidak yakin akan pengetahuan, kemampuan, dan keahlian dirinya dalam berinvestasi menjadi yakin akan pengetahuan, kemampuan, dan keahlian dirinya dalam berinvestasi tersebut maka keputusan investasinya akan mengalami peningkatan. Penjelasan tersebut dapat digambarkan melalui persamaan berikut :

$\mathrm{Y}=-6,337+0,241(5)+0,534(10)-0,737(1)-1,796(1)+7,053(1)-1,335(1)+0,674$

$\mathrm{Y} \quad=4,067$

Angka 4,067 dari variabel keputusan investasi tersebut memiliki arti : 1) dana yang digunakan untuk berinvestasi sebesar Rp15.335.000,-, 2) pengalaman berinvestasi di pasar modal sudah 12 tahun, 3) frekuensi transaksi saham minimal 6 hari sekali, dan 4) respon pada saat mengalami kerugian responsif. Oleh karena itu, dapat saya simpulkan bahwa ketika seorang menaikkan overconfidence-nya maka keputusan investasinya akan mengalami peningkatan juga.

Untuk variabel kontrol pendidikan memiliki koefien yang sangat besar yaitu 7,053, yang memiliki arti bahwa pendidikan investor memiliki pengaruh yang sangat besar terhadap keputusan investasi investor tersebut. Penjelasan tersebut dapat digambarkan melalui persamaan berikut :

$\mathrm{Y}=-6,337+0,241(5)+0,534(5)-0,737(1)-1,796(1)+7,053(2)-1,335(1)+0,674$

$\mathrm{Y} \quad=8,45$

Angka 8,45 dari variabel keputusan investasi tersebut memiliki arti : 1) dana yang digunakan untuk berinvestasi di atas Rp20.000.000,-, 2) pengalaman berinvestasi di pasar modal sudah di atas 16 tahun, 3) frekuensi transaksi saham minimal 1 hari sekali, dan 4) respon pada saat mengalami kerugian sangat responsif. Oleh karena itu, dapat saya simpulkan bahwa ketika seorang investor memiliki pendidikan yang tinggi maka keputusan investasinya akan mengalami peningkatan yang sangat besar.

Untuk variabel lainnya yang memiliki koefisien yang negatif adalah variabel kontrol jenis kelamin, usia, dan pendapatan. Untuk variabel jenis kelamin menunjukkan koefisien sebesar -0,737 yang berarti investor wanita (score 2) memiliki keputusan yang kurang baik dibandingkan dengan keputusan dari investor pria (score 1). Sehingga jika investor wanita melakukan transaksi saham maka keputusan investasinya akan turun sebesar -0,737 satuan. Dan jika investor pria melakukan transaksi saham maka keputusan investasinya akan meningkat sebesar 0,737 satuan dengan asumsi variabel yang lain dianggap konstan.

Untuk variabel usia menunjukkan koefisien sebesar -1,796 yang berarti investor yang usianya di bawah 30 tahun (score 1) memiliki keputusan investasi yang kurang baik dibandingkan dengan investor yang 
usianya di atas 30 tahun. Sehingga jika investor yang usianya di bawah 30 tahun melakukan transaksi saham maka keputusan investasinya akan turun sebesar -1,796 satuan. Sebaliknya, apabila investor yang usianya di atas 30 tahun melakukan transaksi saham maka keputusan investasinya akan naik sebesar 1,796 satuan dengan asumsi variabel lain dianggap konstan.

Variabel pendapatan menunjukkan koefisien sebesar $-1,335$ yang berarti investor yang memiliki pendapatan per bulan di bawah Rp10.000.000,- memiliki keputusan investasi yang kurang baik dibandingkan dengan investor yang memiliki pendapatan per bulan di atas Rp10.000.000,-. Sehingga jika investor yang memiliki pendapatan per bulan di bawah Rp10.000.000,- melakukan transaksi saham maka keputusan investasinya akan turun sebesar -1,335 satuan. Sebaliknya, jika investor yang memiliki pendapatan per bulan di atas Rp10.000.000,- melakukan transaksi saham maka keputusan investasinya akan naik sebesar 1,335 satuan dengan asumsi variabel lain dianggap konstan.

\section{Hasil Penelitian}

Variabel kompetensi $\left(\mathrm{X}_{1}\right)$ sig. 0,011 kurang dari 0,005 atau 5\%, hal ini menunjukkan variabel kompetensi signifikan secara parsial mempengaruhi keputusan investasi. Dari koefisien regresi pada model regresi menunjukkan angka 0,241. Maka kesimpulannya bahwa variabel kompetensi signifikan positif mempengaruhi keputusan investasi.

Variabel overconfidence $\left(\mathrm{X}_{2}\right)$ sig. 0,000 kurang dari 0,05 atau 5\%, hal ini menunjukkan variabel overconfidence secara parsial signifikan mempengaruhi keputusan investasi. Dari koefisien regresi pada model regresi menunjukkan angka 0,534. Maka kesimpulannya bahwa variabel overconfidence signifikan positif mempengaruhi keputusan investasi.

Variabel kompetensi dan overconfidence signifikan mempengaruhi keputusan investasi. Dari koefisien regresi pada model regresi menunjukkan angka 0,241 untuk variabel kompetensi dan angka 0,543 untuk variable overconfidence. Maka kesimpulannya bahwa variabel kompetensi dan overconfidence signifikan positif mempengaruhi keputusan investasi.

Pada Tabel 3 menunjukkan besarnya Adjusted $R$ Squareadalah 0,508, yang artinya sebesar 50,8\% variasi variabel keputusan investasi $(\mathrm{Y})$ dapat dijelaskan oleh variasi variabel kompetensi $\left(\mathrm{X}_{1}\right)$ dan overconfidence $\left(\mathrm{X}_{2}\right)$, sisanya sebesar 49,2\% dijelaskan oleh variabel lainnya, yaitu likuiditas, kesempatan investasi, profitabilitas dan hutang.

\section{A. PEMBAHASAN}

Jika dilihat dari tingkat signifikansinya, dari keempat variabel kontrol yang ada, hanya variabel pendidikan yang signifikan mempengaruhi keputusan investasi. Hal ini sejalan dengan Kimball et al. (2007: 20) dan Graham et al. (2009) yang menyatakan bahwa investor yang pendidikannya tinggi memiliki pengetahuan yang lebih banyak mengenai pergerakan saham dan lebih berani dalam mengambil resiko sehingga pengambilan keputusannya dalam berinvestasi lebih besar dibandingkan dengan investor yang pendidikannya lebih rendah.

Glaser et. al (2013) menyatakan bahwa pengetahuan mengenai investasi yang dimiliki oleh investor akan membuat investor cenderung menjadi lebih percaya diri dan kemudian investor tersebut akan melakukan perdagangan saham yang akhirnya menyebabkan keputusan investasinya menjadi lebih besar.

Kompetensi investor signifikan positif mempengaruhi keputusan investasi. Keputusan dalam berinvestasi dipengaruhi oleh kompetensi investor yang berpendidikan tinggi (minimal Sarjana). Hasil penelitian ini sejalan dengan penelitian yang dilakukan oleh Graham dkk. (2009) yang menyatakan bahwa ketika investor cenderung merasa kompeten, maka investor tersebut akan lebih sering melakukan perdagangan saham yang akhirnya menyebabkan frekuensi transaksi menjadi lebih tinggi dan Chandra (2009) yang menunjukkan bahwa investor dengan tingkat kompetensi yang tinggi akan lebih sering melakukan perdagangan saham.

Kompetensi investor di pasar saham mencerminkan adanya financial literacy yang merujuk pada pemahaman investor mengenai bagaimana pasar keuangan bekerja. Status pendidikan seorang investor secara garis besar dapat menunjukkan seberapa besar financial literacy yang dimiliki oleh investor tersebut. Menurut Chandra (2009), dengan kompetensi yang lebih tinggi, investor dengan latar belakang pendidikan yang lebih tinggi cenderung untuk mengambil keputusan lebih sering mengenai kegiatan perdagangan di pasar saham. Temuan ini sejalan dengan pemikiran bahwa investor yang berkualitas tinggi akan merasa 
lebih kompeten di pasar modal dan cenderung untuk bertransaksi lebih banyak dibandingkan dengan investor dengan latar belakang pendidikan yang kurang baik.

Faktor pengalaman juga merupakan salah satu faktor yang mempengaruhi kompetensi yang dimiliki oleh investor dalam melakukan perdagangan saham. Investor yang memiliki pengalaman berinvestasi yang banyak menandakan bahwa investor tersebut memiliki kemampuan mengambil keputusan dalam bertransaksi yang lebih baik jika dibandingkan dengan investor yang kurang berpengalaman. Hal ini dikarenakan investor yang memiliki pengalaman yang lebih akan memiliki pengetahuan yang lebih baik dalam menghadapi situasi tertentu yang mungkin terjadi dan menjadi semakin kompeten dalam melakukan perdagangan saham (Heath dan Tversky 1991).

Overconfidence signifikan positif secara parsial mempengaruhi keputusan investasi. Seorang investor yang overconfidence akan memiliki keputusan investasi yang lebih besar. Hasil penelitian ini sejalan dengan penelitian yang dilakukan oleh Odean, 1999; Barber and Odean, 2001; Statman et.al, 2003 berdasarkan penelitian empiris menemukan bahwa tingkat trading activity dari seorang investor dipengaruhi oleh tingkat overconfidence dari investor tersebut, semakin investor memiliki overconfidence, semakin sering dia melakukan trading (perdagangan).

Penelitian ini juga sejalan dengan penelitian yang dilakukan oleh Glaser and Weber (2003), Wibisono (2013) yang berpendapat bahwa seorang investor yang menganggap dirinya memiliki kemampuan yang lebih dari rata-rata atau dapat diartikan seorang yang memiliki kepercayaan diri yang tinggi akan melakukan transaksi saham lebih banyak. Seorang investor yang overconfidence akan memiliki keyakinan dalam mengambil keputusan dan lebih berani dalam mengambil resiko saat melakukan transaksi saham karena menurut dirinya memiliki kemampuan dan keahlian yang lebih daripada orang lain.

Kompetensi dan overconfidence signifikan positif secara simultan mempengaruhi keputusan investasi. Kompetensi dan overconfidence secara bersama-sama mempengaruhi keputusan investasi. Semakin besar kompetensi dan overconfidence seorang investor semakin besar pula keputusan investasi yang di ambil.

\section{Tabel 4}

Matriks Konsistensi Penelitian

\begin{tabular}{|c|c|c|c|}
\hline No. & Peneliti (Tahun) & $\begin{array}{l}\text { Kesimpulan dari penelitian } \\
\text { terdahulu }\end{array}$ & $\begin{array}{l}\text { Kesimpulan dari penelitian } \\
\text { ini }\end{array}$ \\
\hline 1. & $\begin{array}{l}\text { Abhijeet Chandra } \\
\text { (2009) }\end{array}$ & $\begin{array}{l}\text { Kompetensi signifikan } \\
\text { berpengaruh positif terhadap } \\
\text { trading frequency. }\end{array}$ & $\begin{array}{l}\text { Kompetensi investor } \\
\text { signifikan berpengaruh } \\
\text { positif terhadap keputusan } \\
\text { investasi. }\end{array}$ \\
\hline 2. & $\begin{array}{l}\text { Markus Glaser and } \\
\text { Martin Weber } \\
(2003)\end{array}$ & $\begin{array}{l}\text { Overconfidence signikan } \\
\text { berpengaruh positif terhadap } \\
\text { trading volume. }\end{array}$ & $\begin{array}{l}\text { Overconfidence signifikan } \\
\text { berpengaruh positif } \\
\text { terhadap keputusan } \\
\text { investasi. }\end{array}$ \\
\hline 3. & $\begin{array}{l}\text { Okky Putrie } \\
\text { Wibisono (2013) }\end{array}$ & $\begin{array}{l}\text { Overconfidence, } \\
\text { kompetensi, dan pendapatan } \\
\text { signifikan berpengaruh } \\
\text { positif terhadap perilaku } \\
\text { perdagangan saham. } \\
\text { Jenis kelamin tidak } \\
\text { signifikan dan berpengaruh } \\
\text { negatif terhadap perilaku } \\
\text { perdagangan saham. }\end{array}$ & $\begin{array}{l}\text { Overconfidence, } \\
\text { kompetensi, dan } \\
\text { pendidikan signifikan } \\
\text { berpengaruh positif } \\
\text { terhadap keputusan } \\
\text { investasi. } \\
\text { Jenis kelamin tidak } \\
\text { signifikan dan } \\
\text { berpengaruh negatif } \\
\text { terhadap keputusan } \\
\text { investasi. }\end{array}$ \\
\hline 4. & Kimball et. al (2007) & $\begin{array}{l}\text { Pendidikan signifikan } \\
\text { berpengaruh positif terhadap }\end{array}$ & $\begin{array}{l}\text { Pendidikan signifikan } \\
\text { berpengaruh positif }\end{array}$ \\
\hline
\end{tabular}




\begin{tabular}{|l|l|l|l|}
\hline & & risk tolerance. & $\begin{array}{l}\text { terhadap keputusan } \\
\text { investasi. }\end{array}$ \\
\hline 5. & $\begin{array}{l}\text { Muhammad Nauman } \\
\text { Sadiq \& Hafiz } \\
\text { Muhammad Ishaq } \\
\text { (2014) }\end{array}$ & $\begin{array}{l}\text { Pendidikan signifikan } \\
\text { berpengaruh positif terhadap } \\
\text { keputusan investasi. } \\
\text { Jenis kelamin tidak } \\
\text { signifikan dan berpengaruh } \\
\text { negative terhadap keputusan } \\
\text { investasi. }\end{array}$ & $\begin{array}{l}\text { Pendidikan signifikan } \\
\text { berpengaruh positif } \\
\text { terhadap keputusan } \\
\text { investasi. } \\
\text { Jenis kelamin tidak } \\
\text { signifikan dan } \\
\text { berpengaruh negatif } \\
\text { terhadap keputusan } \\
\text { investasi. }\end{array}$ \\
\hline 6. & $\begin{array}{l}\text { John R. Graham, } \\
\text { Campbell R. Harvey, } \\
\text { Hai Huang (2005) }\end{array}$ & $\begin{array}{l}\text { Kompetensi investor } \\
\text { signifikan berpengaruh } \\
\text { positif terhadap trading } \\
\text { volume. }\end{array}$ & $\begin{array}{l}\text { Kompetensi investor } \\
\text { signifikan berpengaruh } \\
\text { positif terhadap keputusan } \\
\text { investasi. }\end{array}$ \\
\hline 7. & $\begin{array}{l}\text { Colleen Tokar } \\
\text { Asaad, Bryan C. } \\
\text { McCannon, Mark } \\
\text { Wilson (2014) }\end{array}$ & $\begin{array}{l}\text { Overconfidence signifikan } \\
\text { berpengaruh positif terhadap } \\
\text { trusting investment. }\end{array}$ & $\begin{array}{l}\text { Overconfidence signifikan } \\
\text { berpengaruh positif } \\
\text { terhadap keputusan } \\
\text { investasi. }\end{array}$ \\
\hline
\end{tabular}

\section{DAFTAR PUSTAKA}

Barber, M, Brad and Terrance Odean. (2000). Trading is Hazardous to Your Wealth: The Common Stock Investment Performance of Individual Investors. Journal of Finance. Vol 55. No 2. hal. 773-806.

Barber, Brad M., and Terrance Odean. (2001). Boys Will Be Boys: Gender, Overconfidence, and Common stock Investment. Quarterly Journal of Economics. Vol. 116. hal. 261-292.

Bodie, Kane, and Marcus. (2007). Essentials of Investments. Sixth Edition. New York : McGraw Hill.

Chandra, Abhijeet. (2009). 'Individual investor's trading behavior and the competence effect'. Journal of Behavioral Finance. Vol. 6. No. 1. pp. 56-70.

Ellsberg, Daniel. (1961). Risk, Ambiguity and the Savage Axioms. Quarterly Journal of Economics. Vol. LXXV. hal. 643-69.

Fischhoff, Baruch., Paul Slovic, and Sarah Lichtenstein. (1977). Knowing with Certainty: The Appropriateness of Extreme Confidence. Journal of Experimental Psychology: Human Perception and Performance. Vol 3. No. 4. hal. 52-5564. 81

Testing. Psychological Review. Vol. 94. hal. 211-228. 82

Graham, J., Harvey, C., Huang, H. (2005). Investor Competence, Trading Frequency, and Home Bias. NBER Working Paper.

Heath, C., Tversky, A. (1991). Preference and belief: Ambiguity and Competence in Choice Under Uncertainty. Journal of Risk and Uncertainty. Vol. 4. hal. 5-28.

Husnan, Suad. (2009). Dasar-dasar Teori Portofolio dan Analisis Sekuritas, Edisi Keempat. Yogyakarta : UPP AMP YKPN.

Jones, Charles P. (2004). Investment Analysis and Management. 9th ed. New York : John Wiley and Sons.

Kahneman, D., and A. Tversky. (1979). Prospect Theory: An Analysis of Decision Under Risk. Econometrica. Vol. 47. hal. 263-291.

Kahneman, D., and A. Tversky. (1984). Choices, Values and Frames. American Psychologist. Vol. 39. hal. 341-350.

Kahneman, D., and Theversky, A. (2000). Choices, Values and Frames. Cambridge: Cambridge University Press.

Karlsson, Anders and Lars Nordén. (2007). Investor Competence, Information and Investment Activity. Working paper. SSRN. 


\section{DAN PENDIDIKAN.}

Klayman, Joshua., and Ha, Y, W. (1987). Confirmation, Disconfirmation and Information in Hypothesis Kufepaksi, Mahatma. (2007). The Effect of Overconfident Behavior on the Process of Forming and Correcting The Values of The Security in Market Experiment: The Implication of Self Deceptive Behavior in a Security Market. Dissertation. Unpublished.

Lewellen, W., Lease, R., Schlarbaum, G. (1977). Patterns of investment strategy and behavior among individual investors. Journal of Business. Vol. 50. pp. 296-333.

Lichtenstein, Sarah., Fischhoff, Baruch., and Lawrence D Phillips. (1982). Calibration of Probabilities: The State of The Art To 1980. Judgement Under Uncertainty : Heuristics and Biases. Edited by Daniel Kahneman, Paul Slovic and Amos Tversky. Cambridge, UK and New York : Cambridge University Press : 306 -334.

Lutfi. (2010). The relationship between demographics factors and investment decision in Surabaya. Jurnal of Economics: Business and Accountancy Ventura. Vol. 13. No. 3. pp. 213-224.

Odean, Terrance. (1998). Are Investors Reluctant to Realize Their Losses?. Journal of Finance. Vol. 53. No. 5. pp. 1775-1798.

Odean, Terrance. (1999). Do Investors Trade Too Much?. American Economics Review. Vol. 89. hal. 12791298.

Nofsinger, John R. (2005). Investment Madness: How Psychology Affects Your Investing and What to Do About It. New Jersey: Prentice Hall. 83

Pompian, Michael M. (2006). Behavioral Finance and Wealth Management. New York: John Wiley \& Sons Inc.

Ricciardi, V. \& Simon, H.K. (2000). What is Behavioral Finance?. Business, Education and Technology Journal Fall 2000.

Rr. Iramani dan Dhyka Bagus. (2008). Faktor-faktor penentu perilaku investor dalam transaksi saham di Surabaya. Jurnal Aplikasi Manajemen. Vol. 6. No. 3. hal. 255-262.

Saragih, Joana L. (2008). Faktor-Faktor yang Mempengaruhi Keputusan Investasi Pada Perusahaan Barang Konsumsi Di Bursa Efek Indonesia. Tesis. Fakultas Ekonomi Universitas Sumatera Utara.

Shefrin, Hersh. (2000). Beyond Greed and Fear: Understanding Behavioral Finance and Psychology of Investing. Harvard Business School Press.

Shefrin, Hersh and Meir Statman. (2000). Behavioral Portfolio Theory. Journal of Financial and Quantitative Analysis. Vol. 35. No. 2. pp. 127-151.

Shefrin, Hersh. (2005). A Behavioral Approach for Asset Pricing. Elseiver Academic Press.

Sheikh, Muhammad Fayyaz and Khalid Riaz. (2012). Overconfidence Bias, Trading Volume and Returns Volatility: Evidence from Pakistan. World Applied Science Journal. Vol. 18. No. 12. hal. 1737-1748. 84

Suryawijaya, Marwan Asri. (2003). Ketidakrasionalan Investor di Pasar Modal. Pidato Pengukuhan Jabatan Guru Besar pada Fakultas Ekonomi Universitas Gadjah Mada. Yogyakarta.

Yeh, Chia-Hsuan and Chun-Yi Yang. (2009). Examining the Effects of Traders' Overconfidence on Market Behavior. Agent-Based Approaches in Economic and Social Complex Systems VI: Post-Proceedings of The AESCS International Workshop 2009. DOI 10.1007/978-4-431-53907.

Yohnson. (2008). Regret Aversion dan Risk Tolerance Investor Muda Jakarta dan Surabaya. Jurnal Manajemen dan Kewirausahaan. Vol. 10. No. 2. hal. 163-168.

BPS Provinsi DKI Jakarta. (2015). Statistik Jumlah Penduduk. http://bappedajakarta.go.id/?page_id=1131

BEI Press Release. (2015). BEI Siap Memacu Langkah Menuju Bursa Berstandar Internasional. http://www.idx.co.id/Home/NewsAndAnnouncement/PressRelease/ReadPressRelease/tabid/191/ItemI D/4d01f734-fe3d-4185-938b-534c5998dca0/language/id-ID/Default.aspx 